\title{
CHIPS for a Mutation Screening of a Large Sized Gene: An example of NF1 Analysis \\ Yo Niida*
}

Division of Genomic Medicine, Department of Advanced Medicine, Medical Research Institute, Kanazawa Medical University, Ishikawa, Japan

\section{Introduction}

At present, gold standard method of genetic testing is still whole coding exon sequencing by Sanger method. However, this approach is expensive and time consuming, when the disease causative gene has a large number of exons and you have to sequence all of them because of no mutational hot spots. A good example of this situation is the NF1 gene which includes 58 coding exons. NF1 is a causative gene of neurofibromatosis type I (NF1 [MIM 162200]), one of the most common autosomal dominant disorders, occurring with an incidence of 1 in 2,500 to 3,000 individuals. NF1 is characterized by multiple café-au-lait spots, Lisch nodules in the iris, and fibromatous tumors of the skin [1]. A summary of the previous studies shows more than $90 \%$ of these patients have NF1 small sequence variants thoroughout the NF1 gene [2].To address this problem, we recently developed CHIPS (CEL nuclease mediated heteroduplex incision with polyacrylamide gel electrophoresis and silver staining) technology for a mutation screening of a large sized gene, and it was applied to NF1 analysis [3]. CHIPS is based on enzyme mismatch cleavage (EMC) method, and finely optimized at every step to achieve maximum sensitivity and simplicity. Actually $100 \%$ sensitivity of mutation detection has been accomplished using only commercially available reagents and basic apparatus $[4,5]$. At the same time, CHIPS offers inexpensive easy mutation screening by cutting out the cost and effort of unnecessary sequencing [6]. Here we demonstrate an example of mutation screening of a patient with NF1.

\section{Protocol}

Peripheral blood leukocyte DNA was extracted from a patient with $\mathrm{NF} 1$. Exon 1 of NF1 is located in a GC rich region and required separate amplification using with KOD -Plus- Ver 2. polymerase (Toyobo). The PCR product was determined by direct sequencing without CHIPS screening [3].

For exon 2 to 58, PCR were performed with two different annealing temperatures $(\mathrm{Ta})$, either $58^{\circ} \mathrm{C}$ or $60^{\circ} \mathrm{C}$, depending on the primer set. The PCR cycle parameters were held at $94^{\circ} \mathrm{C}$ for $5 \mathrm{~min}$ (initial denaturation), followed by 7 cycles of $97^{\circ} \mathrm{C}$ for $10 \mathrm{sec}$ and $\mathrm{Ta}+7^{\circ} \mathrm{C}$ for $10 \mathrm{sec}$ with the annealing temperature being decreased at a rate of $1^{\circ} \mathrm{C}$ per cycle (touch down cycles for reducing non-specific PCR products), followed by $30 \mathrm{cycles}$ of $96^{\circ} \mathrm{C}$ for $10 \mathrm{sec}$, Ta ${ }^{\circ} \mathrm{C}$ for $10 \mathrm{sec}$ (amplification cycles), then held at $72^{\circ} \mathrm{C}$ for $2 \mathrm{~min}$ for the final extension. PCR reaction were performed in a $10 \mu \mathrm{l}$ volume with $50 \mathrm{ng} / \mu \mathrm{l}$ of template DNA, $0.4 \mu \mathrm{M}$ of both forward and reverse primers, and 0.2 unit of Taq DNA polymerase (Roche) for $\mathrm{Ta}=58^{\circ} \mathrm{C}$ and 0.25 units of Blend Taq -plus- (Toyobo) for $\mathrm{Ta}=60^{\circ} \mathrm{C}$. PCR primer sequences are available on elsewhere [3].

Heteroduplex DNA was successively produced on a thermal cycler using the following program: $85^{\circ} \mathrm{C}$ for $15 \mathrm{~min}$ and $95^{\circ} \mathrm{C}$ for $5 \mathrm{~min}$ (for complete denaturation of the PCR products) then increase the temperature once to $97^{\circ} \mathrm{C}$ and reduce to $25^{\circ} \mathrm{C}$ by $-1^{\circ} \mathrm{C}$ per min (for heteroduplex formation).

One $\mu \mathrm{l}$ of heteroduplex substrate was incubated with $0.05 \mu \mathrm{l}(0.5 \mathrm{U})$ of SURVEYOR Nuclease S (Transgenomic), $10 \mathrm{mM}$ Tricin ( $\mathrm{pH} 9.0$ ) and $1.5 \mathrm{mM} \mathrm{MgCl}_{2}$ in $5 \mu \mathrm{l}$ of reaction volume at $42^{\circ} \mathrm{C}$ for $30 \mathrm{~min}$. One $\mu \mathrm{l}$ of heteroduplex substrate was used for undigested control, and the remaining samples were stored at $-20^{\circ} \mathrm{C}$ for DNA sequencing.

The samples were mixed with $3 \mu$ of Type I gel loading buffer (40\% sucrose, $0.02 \%$ bromophenol blue) and separated on $10 \%$ polyacrylamide gels (Acr/Bis=29:1, 5\% glycerol) for $80 \mathrm{~min}$ at $17 \mathrm{~V} /$ $\mathrm{cm}$ in $1 \mathrm{x}$ TBE.

The gels were developed by optimized silver staining method [7], with the modifications as following. The gel was rinsed in deionized water briefly, and incubated in $0.1 \% \mathrm{AgNO}_{3}(\mathrm{w} / \mathrm{v})$ for $5 \mathrm{~min}$ at room temperature with gentle agitation. Discard the $\mathrm{AgNO}_{3}$ solution and rinse the gel in deionized water briefly. Then incubated with $0.04 \%$ $\mathrm{Na}_{2} \mathrm{CO}_{3}(\mathrm{w} / \mathrm{v}), 0.5 \% \mathrm{NaOH}(\mathrm{w} / \mathrm{v})$ and $0.074 \% \mathrm{HCOH}(0.2 \mathrm{ml}$ of $37 \%$ $\mathrm{HCOH}$ per $100 \mathrm{ml}$ ) for 5 to $10 \mathrm{~min}$ at room temperature to develop the gel. After developing a sufficient intensity of the bands, the gel was rinsed with deionized water briefly, and the reaction was stopped with $5 \%$ acetic acid.

DNA sequencing was performed with the BigDye Terminator v3.1 cycle sequencing kit and ABI PRISM $3100 \mathrm{xl}$ Genetic analyzer (Applied Biosystems).

\section{Results}

In CHIPS gels, comparing to the original band, completely cleaved heteroduplex bands are appeared at lower portion of the gel, because of its short lengths and rapid migration. Also, partially cleaved or uncleaved heteroduplex bands are appeared at upper portion, because of slow migration in the gel. Ten primer sets showed these sift bands (Figure 1A). Direct sequence confirmed novel NF1 nonsense mutation Gln209* in exon 6 (Figure 1B), and seven polymorphisms (Table 1). We noticed that ladder bands appeared in exons 7, 14, 25 and in 42 PCR products. These PCR products include poly $\mathrm{T}$ or A stretch, making it difficult to distinguish true polymorphisms from artificial PCR slippage errors. Then, we compared the CHIPS results of the patient and hemizygous control; i.e., DNA from the patient with NF1 large deletion at genomic level, which never made a NF1 heteroduplex (Figure 1C). Finally, we concluded that exons 25 and 42 were caused by PCR slippage error of poly T/A stretches, while exon 7 and 14 are true

*Corresponding author: Yo Niida, M.D., Ph.D., Divisions of Genomic Medicine Department of Advanced Medicine, Medical Research Institute, Kanazawa Medical University, 1-1 Daigaku, Uchinada, Ishikawa 920-0293, Japan; Tel: +81 076-2862211 (ext. 8353); Fax: +81 076-286-5002; E-mail: niida@kanazawa-med.ac.jp

Received October 13, 2015; Accepted November 06, 2015; Published November 09, 2015

Citation: Niida Y (2015) CHIPS for a Mutation Screening of a Large Sized Gene: An example of NF1 Analysis. Pharm Anal Acta 6: 440. doi:10.4172/21532435.1000440

Copyright: @ 2015 Niida Y. This is an open-access article distributed under the terms of the Creative Commons Attribution License, which permits unrestricted use, distribution, and reproduction in any medium, provided the original author and source are credited. 
Citation: Niida Y (2015) CHIPS for a Mutation Screening of a Large Sized Gene: An example of NF1 Analysis. Pharm Anal Acta 6: 440. doi:10.4172/21532435.1000440

Page 2 of 2

A ${ }^{2}=58^{\circ} \mathrm{C}$ series

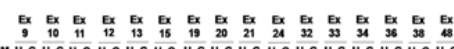

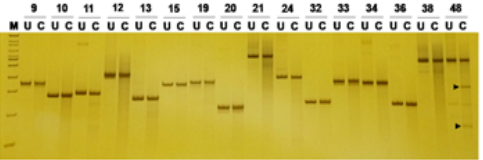

$\mathrm{Ta}=60^{\circ} \mathrm{C}$ series

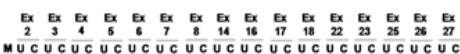
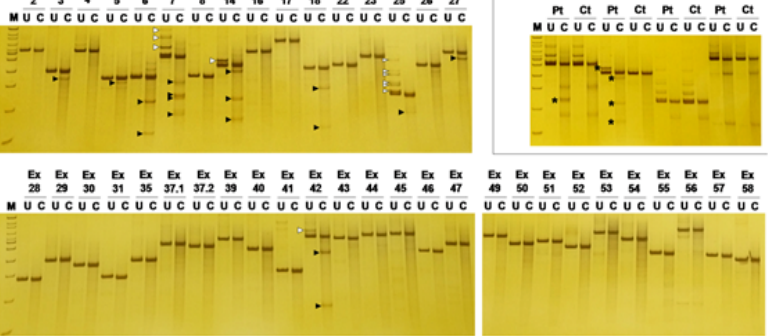

Figure 1: The NF1 analysis results of the patient. CHIPS analysis was performed either $58^{\circ} \mathrm{C}$ or $60^{\circ} \mathrm{C}$ annealing temperature series. Cleaved heteroduplex bands are indicated by black arrow heads and shifted bands by heteroduplex formations are indicated by white arrow heads (A). Novel NF1 nonsense mutation, GIn209* was detected in exon 6 (B). To distinguish PCR slippage error by poly T/A stretch from real polymorphism, compared CHIPS results of the patient and hemizygous control (large NF1 deletion) for exon 7 , 14,25 and 42 . Unique cleavage bands $\left(^{*}\right)$ are detected in exon 7 and 14 , but not in exon 25 and 42 (C). M, molecular weight marker; $U$, undigested control of PCR product; C, cleaved PCR product with SURVEYOR Nuclease S.

\begin{tabular}{|c|c|c|c|c|}
\hline Primer set & Position & DNA level & Protein level & $\begin{array}{c}\text { Significance } \\
\text { polymorphism } \\
\text { (rs2952976) }\end{array}$ \\
\hline Ex 3 & Intron 3 & c.288+41G>A & & $\begin{array}{c}\text { polymorphism } \\
\text { (rs2905807) }\end{array}$ \\
\hline Ex 6 & Intron 4 & c.480-90C>T & p.GIn209* & $\begin{array}{c}\text { disease } \\
\text { causative } \\
\text { mutation }\end{array}$ \\
\hline Ex 7 & Exon 7 & c.702G>A & p.Leu234= & $\begin{array}{c}\text { polymorphism } \\
\text { (rs1801052) }\end{array}$ \\
\hline Ex 14 & Intron 13 & c.1528-35T[8] & & polymorphism \\
\hline Ex 18 & Exon 18 & c.2034G>A & p.Pro678= & $\begin{array}{c}\text { polymorphism } \\
\text { (rs2285892) }\end{array}$ \\
\hline Ex 27 & Intron 26 & c.3496+33C>A & & $\begin{array}{c}\text { polymorphism } \\
\text { (rs2066736) }\end{array}$ \\
\hline Ex 48 & Intron 48 & c.7126+37C>G & & $\begin{array}{c}\text { polymorphism } \\
\text { (rs7405740) }\end{array}$ \\
\hline & & & & \\
\hline
\end{tabular}

Table 1: Summary of detected mutations and polymorphisms polymorphisms. Exon7 polymorphism was detected as unique cleaved band in the background of the ladder.

\section{Discussion}

An ideal mutation screening method would require using only conventional equipment and reagents; a single universal experimental protocol that can be applied to any genes and mutation types; the ability to handle long PCR fragments; and would achieve high sensitivity, high throughput and high cost performance. Based on these criteria, EMC may become one of the ideal mutation screening methods when the sensitivity of the enzyme is sufficiently high. To actualize this concept, we optimized each step of EMC and developed CHIPS as shown here. To analyze this patient, we finished screening of NF1 mutations within a day, and confirmed DNA sequences and the diagnosis at the next day. We conclude that CHIPS technology is useful and facilitates DNA diagnosis in a clinical setting. CHIPS adapted to not only autosomal dominant disease but also to autosomal recessive and X-linked disease by simple mixing of patient and control DNA [5]. Also, CHIPS can use for screening of SNPs (single nucleotide polymorphisms) in a large amount samples; can works as well as the PCR-RFLP (restriction fragment length polymorphism), even if there is no specific restriction enzyme. This system does not use any special instruments; rather, it uses conventional equipment and commercially available reagents. This is the greatest advantage of this system. Because of its superficial low technology, any researchers-including those who are working in a disadvantaged scientific environment-can begin to use this system immediately.

\section{Acknowledgment}

This work was supported by JSPS KAKENHI grant (no. 22591122).

\section{References}

1. Guttmann DH, Aylsworth A, Carey JC, Korf B, Marks J, et al. (1997) The diagnostic evaluation and multidisciplinary management of neurofibromatosis 1 and neurofibromatosis 2. JAMA 278: 51-7.

2. Kluwe L, Siebert R, Gesk S, Friedrich RE, Tinschert S, et al. (2004) Screening 500 unselected neurofibromatosis 1 patients for deletions of the NF1 gene. Hum Mutat 23: 111-6.

3. Okumura A, Ozaki M, Niida Y (2015) Development of a practical NF1 genetic testing method through the pilot analysis of five Japanese families with neurofibromatosis type 1. Brain Dev 37: 677-89.

4. Tsuji T, Niida $Y$ (2008) Development of a simple and highly sensitive mutation screening system by enzyme mismatch cleavage with optimized conditions for standard laboratories. Electrophoresis 29: 1473-1483.

5. Niida Y, Kuroda M, Mitani Y, Okumura A, Yokoi A (2012) Applying and testing the conveniently optimized enzyme mismatch cleavage method to clinical DNA diagnosis. Mol Genet Metab 107: 580-585.

6. Niida Y, Ozaki M, Inoue M, Takase E, Kuroda M, et al. (2015) CHIPS for genetic testing to improve a regional clinical genetic service. Clin Genet 88: 155-160.

7. Ji Y, Qu C, Cao B (2007) An optimal method of DNA silver staining in polyacrylamide gels. Electrophoresis $28 ; 1173-1175$ 